\title{
Annual cycle of dimethylsulfoniopropionate (DMSP) and dimethylsulfoxide (DMSO) related to phytoplankton succession in the Southern North Sea
}

\author{
Gaëlle Speeckaert ${ }^{\mathrm{a}, \mathrm{b}}$, Alberto V. Borges ${ }^{\mathrm{b}}$, Willy Champenois ${ }^{\mathrm{b}}$, Colin Royer ${ }^{\mathrm{a}, \mathrm{b}}$, Nathalie Gypens ${ }^{\mathrm{a}, *}$ \\ ${ }^{a}$ Écologie des Systèmes Aquatiques, Université Libre de Bruxelles, Belgium \\ ${ }^{\mathrm{b}}$ Unité d'Océanographie Chimique, Université de Liège, Belgium
}

\section{A R T I C L E I N F O}

\section{Article history}

Received 10 October 2017

Received in revised form 30 November 2017

Accepted 30 November 2017

Available online $\mathrm{xxx}$

Editor: D. Barcelo

Keywords:

Dimethyl sulfide

Dimethylsulfoniopropionate

Dimethylsulfoxide

Phytoplankton

Phaeocystis

North Sea

\begin{abstract}
A B S T R A C T
The influence of abiotic and biotic variables on the concentration of dimethyl sulfide (DMS), dimethylsulfoniopropionate (DMSP), and dimethylsulfoxide (DMSO), were investigated during an annual cycle in 2016 in the Belgian Coastal Zone (BCZ, North Sea). We reported strong seasonal variations in the concentration of these compounds linked to the phytoplankton succession with high DMS(P,O) producers (mainly Phaeocystis globosa) occurring in spring and low $\operatorname{DMS}(\mathrm{P}, \mathrm{O})$ producers (various diatoms species) occurring in early spring and autumn. Spatial gradients of DMS and DMSP were related to those of phytoplankton biomass itself related to the inputs of nutrients from the Scheldt estuary. However, the use of a relationship with Chlorophyll- $a(\mathrm{Chl}-a)$ concentration is not sufficient to predict DMSP. Accounting for the phytoplankton composition, two different DMSP versus Chl- $a$ correlations could be established, one for diatoms and another one for Phaeocystis colonies. We also reported high nearshore DMSO concentrations uncoupled to Chl- $a$ and DMSP concentrations but linked to high suspended particulate matter (SPM) presumably coming from the Scheldt estuary as indicated by the positive relationship between annual average SPM and salinity.
\end{abstract}

(C) 2017 .

\section{Introduction}

Dimethylsulfoniopropionate (DMSP) and dimethylsulfoxide (DMSO) are sulfur (S) containing organic molecules produced by some species of phytoplankton, macroalgae and angiosperms (Keller et al., 1989; Hatton and Wilson, 2007; Borges and Champenois, 2017) and the primary precursors of dimethylsulfide (DMS). DMS emissions from the oceans play an important role in the global $\mathrm{S}$ cycle, contributing to approximately $40 \%$ of the biogenic S emissions (Wang et al., 2015) and could act on climate through the formation of atmospheric aerosols and the modification of cloud albedo (Charlson et al., 1987). However, the significance of this feedback on climate remains uncertain (Quinn and Bates, 2011; Green and Hatton, 2014). DMS emissions depend directly on surface water DMS concentration which is regulated by marine microorganisms and abiotic processes such as photo-oxidation. When released in the water through exudation, lysis of senescent cells, grazing or viral attack, DMSP and DMSO are involved in a complex chain of phytoplanktonic and bacterial processes leading, among others, to their transformation into DMS (Stefels et al., 2007). Although DMSP and DMSO are produced by phytoplankton, correlating DMS production with phytoplankton biomass (generally expressed in term of Chlorophyll $a$ ) is challenging (Kettle et al., 1999) because DMSP and DMSO production are species-specific and vary with environmental conditions (e.g. Stefels et al., 2007). Therefore, DMS concentration in seawater is

\footnotetext{
* Corresponding author.

Email address: ngypens@ulb.ac.be (N. Gypens)
}

controlled mainly by phytoplankton composition rather than by algal biomass or production (Masotti et al., 2010).

Since the compilation of DMSP content by 123 phytoplankton species by Keller et al. (1989), we know that Dinophyceae and Haptophyceae are the major DMSP producers and diatoms lower DMSP producers with a few exceptions. Similarly, the biogenic production of DMSO is specific and generally correlated to DMSP production (Hatton and Wilson, 2007). There are different sources of specific variability in DMSP and DMSO production including growth stage, salinity, temperature, nutrient limitation and light related to several potential physiological functions of these molecules as osmoregulator (Vairavamurthy et al., 1985), cryoprotectant (Kirst et al., 1991), antioxidant (Sunda et al., 2002), methyl donor (Kiene et al., 2000), grazing deterrent (Wolfe et al., 1997) and overflow mechanism in nitrogen-limiting conditions (Stefels, 2000). DMSP is also a source of carbon (C) and $\mathrm{S}$ for heterotrophic organisms (Kiene and Linn, 2000a) and acts as a chemical cue for higher trophic level organisms (Steinke et al., 2002). These physiological functions are not necessarily exclusive (Harada and Kiene, 2011) and phytoplankton cells may use several of them.

In the Belgian Coastal Zone (BCZ) of the North Sea, the phytoplankton succession is characterized by a first diatom bloom in late February-early March, followed by a huge biomass peak of Phaeocystis globosa in April-May before summer and autumn diatom blooms (Lancelot et al., 2005) The prymnesiophyte Phaeocystis globosa (referred hereafter as Phaeocystis) forms extensive blooms representing $95 \%$ of the phytoplankton spring community biomass (Rousseau et al., 1990, 2000) and their colonies are estimated as responsible for around $80 \%$ of the total annual DMSP production in 
this zone (Gypens et al., 2014). The area is a permanently well-mixed and eutrophied coastal zone under the influence of the Scheldt and the Rhine rivers. The modification of $\mathrm{C}$ and nutrient river loads to the BCZ observed since the 1950 's led to important changes of primary production, phytoplankton dominance, and $\mathrm{CO}_{2}, \mathrm{CH}_{4}$ and DMS concentrations and emissions (Gypens et al., 2009; Gypens and Borges, 2014; Borges et al., 2017).

Seasonal variations DMSP and DMS have been previously studied in the Southern North Sea (SNS) based on field measurements and model applications (Turner et al., 1988; Kwint and Kramer, 1996; van den Berg et al., 1996; Stefels et al., 1995; van Duyl et al., 1998; Archer et al., 2002; Gypens et al., 2014). All of these studies reported a marked seasonal cycle in $\mathrm{DMS}(\mathrm{P})$ with a maximum in spring (April-May) corresponding to the Phaeocystis bloom followed by a decrease to low winter values. Generally, particulate DMSP (DMSPp) (the intracellular DMSP) represents the main part of the total DMSP (DMSPt) measured in the field, the dissolved DMSP (DMSPd) being quickly consumed or transformed into DMS, DMSO or others degradation products. In the Wadden Sea, van Duyl et al. (1998) measured concentration of DMSPp of about $1650 \mathrm{nmol} \mathrm{L}^{-1}$, and found a significant correlation between DMSPp and the abundance of Phaeocystis cells. Turner et al. (1996) reported maximal values of DMSPp and DMS in the SNS of respectively $450 \mathrm{nmol} \mathrm{L}^{-1}$ and $25 \mathrm{nmol} \mathrm{L}^{-1}$ in May with large concentration gradients over short distances. In the SNS, Liss et al. (1994) have also reported DMS concentrations between 3 and $49 \mathrm{nmol} \mathrm{L}^{-1}$ during the Phaeocystis bloom. In the BCZ, the maximal DMSPp, DMSPd and DMS concentrations simulated by Gypens et al. (2014) respectively reached 580, 210 and $28 \mathrm{nmol} \mathrm{L}^{-1}$ during the Phaeocystis bloom. DMS fluxes follow the patterns of DMS concentrations and are highest closest to the coast and between May and July (Turner et al., 1996; Gypens et al., 2014).

Only a few studies focused on DMSO concentrations in the North Sea because of the later evidence of the existence of particulate DMSO (DMSOp) until recent years (Simó et al., 1998) and its importance for the S cycle (Hatton et al., 2004; Green and Hatton, 2014). Unlike DMS and DMSP that are usually restricted to the euphotic zone, DMSO is ubiquitous and dominant throughout the water column (Hatton et al., 2004). As DMSOp production is also taxon-specific and limited to the same taxons that produce DMSPp (Simó and Vila-Costa, 2006), DMSOp peaks are concomitant or follow those of DMSPp (Hatton and Wilson, 2007). Similarly, a strong relationship exists between DMS and DMSO in surface waters (Hatton et al., 1996, 2004) but no correlation has been found between DMSOp and DMSOd (Hatton and Wilson, 2007); the latter being often greater than DMSOp and DMSPd, because it passively diffuses across cellular membranes unlike DMSP. DMSOd also originates from photochemical and microbial oxidation of DMS (Hatton, 2002).

The current study presents the annual cycle of DMSP, DMSO and DMS concentrations measured in the $\mathrm{BCZ}$ on a regular grid of fixed stations during the year 2016. The study site is characterized by a high variability in abiotic parameters (salinity, temperature and light), and primary production throughout the year and by a similar phytoplankton taxonomic succession from one year to another (Rousseau et al., 2002). In order to improve understanding of biotic and abiotic controls on $\operatorname{DMS}(\mathrm{P}, \mathrm{O})$ distribution in the area, the present study aims to: (1) determine the extent and patterns of spatial and seasonal variations in DMSP, DMSO and DMS concentrations related to changing physico-chemical environmental conditions; (2) determine how these concentrations vary in function of phytoplankton abundance and diversity; and (3) compare DMSP cellular content measured in seawa- ter and in laboratory cultures for key-species of the studied phytoplankton succession.

\section{Material and methods}

\subsection{Field sampling}

Annual monitoring of a range of physical, chemical and biological parameters was carried out at nine fixed stations regularly sampled as part of national water quality monitoring programs by the VLIZ (Vlaams Instituut voor de Zee) and located along three nearshore-offshore transects covering the BCZ (Fig. 1). Samples were collected between January and December 2016, bi-monthly during spring-summer phytoplankton blooms (mid-February to end of June) and monthly during the rest of the year on the RV Simon Stevin. Single samples were carried out at $3 \mathrm{~m}$ depth with a $4 \mathrm{~L}$ Niskin bottle connected to a conductivity-temperature-depth (CTD) probe (Sea-bird SBE25) for further analysis of phytoplankton diversity and abundance, Chlorophyll $a(\mathrm{Chl}-a)$ and DMS(P,O) concentrations. Salinity, temperature and nutrient data were retrieved from the data collected at the same stations and during the same cruises by the VLIZ in the frame of the LifeWatch sampling campaigns (http://rshiny.lifewatch. be/Station\%20data/) (VLIZ, 2017). The surface incident Photosynthetic Active Radiation (PAR) was calculated from the daily global solar radiation data collected at the Oostende station of the Royal Meteorological Institute of Belgium.

\subsection{Phytoplankton laboratory cultures}

Eight phytoplankton species (Asterionella glacialis, Chaetoceros debilis, Chaetoceros socialis, Nitzschia closterium, Rhizosolenia delicatula, Thalassiosira rotula, Skeletonema costatum and the prymnesiophyte Phaeocystis globosa) isolated from seawater samples taken during summer 2013 in the BCZ were put in batch culture under controlled laboratory conditions. All species were grown in 1 or $2 \mathrm{~L}$ batch cultures maintained at $12{ }^{\circ} \mathrm{C}$ on a $12: 12$ dark:light cycle, at a photon flux density of $100 \mu \mathrm{mol}$ quanta $\mathrm{m}^{-2} \mathrm{~s}^{-1}$ supplied by cool-white fluorescent lights. Irradiances were determined with a Heinz Walz US-SQS/A light sensor. The seawater was filtered through a $0.2 \mu \mathrm{m}$ Whatman cellulose acetate filter and sterilized by autoclaving to prevent bacterial contamination. All culture transfers and inoculations were performed in a Clean Air laminar flow hood using standard sterile techniques to maintain axenicity. Culture medium was prepared with filtered seawater enriched with nitrate, ammonium and phosphate concentrations of respectively 50,25 and $5 \mu \mathrm{mol} \mathrm{L}^{-1}$

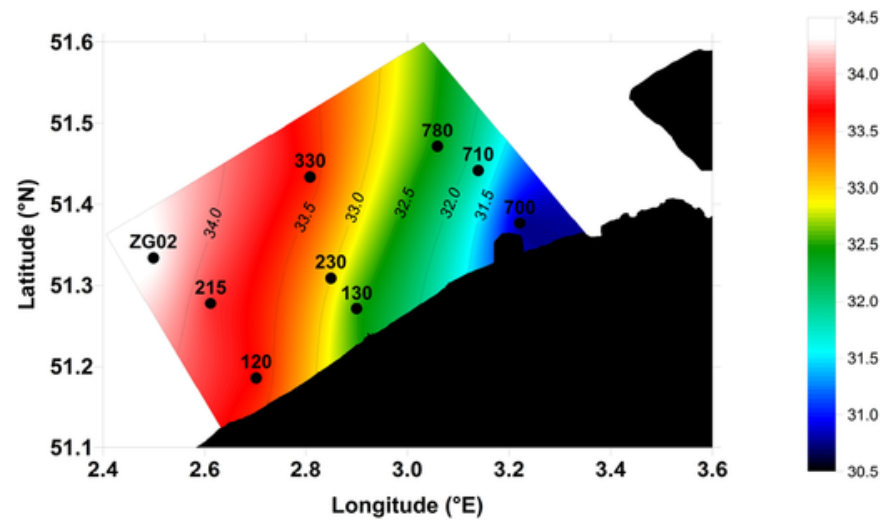

Fig. 1. Averaged salinity in the Belgian coastal waters and the nine sampled stations. 
(Rousseau et al., 1990) or using K medium (A. glacialis, R. delicatula and $T$. rotula) (Keller et al., 1987). Cultures were monitored daily by measuring cell density and Chl- $a$-relative in vivo fluorescence (with a Turner Aquafluor handheld fluorometer). Samples were then collected in mid-exponential growth phase and stored for further analysis of Chl- $a$, cell density and DMS $(\mathrm{P}, \mathrm{O})$ concentration.

\subsection{Phytoplankton composition and biomass}

Samples for Chl- $a$ measurement (100 to $1400 \mathrm{~mL}$ ) were gently filtered onto glass-fiber filters (GF/F) and extracted in $90 \%$ acetone, before applying the fluorometric method of Holm-Hansen et al. (1965) with a Kontron SFM25 fluorimeter. Samples were also fixed with a lugol-glutaraldehyde ( $1 \%$ vol-vol final concentration) and stored at $4{ }^{\circ} \mathrm{C}$ for species identification and cell density measurements by inverted microscopy. Cell density was measured using the Utermöhl method (Hasle, 1978). For Phaeocystis samples, colonies were broken by agitation prior to cell counting. We measured cells linear dimensions for each species identified and assigned it a geometric shape (Hillebrand et al., 1999), from which we calculated specific biovolumes. We converted these biovolumes into specific $\mathrm{C}$ biomass using the equations from Menden-Deuer and Lessard (2000).

\section{4. $\operatorname{DMS}(P, O)$ analysis}

Particulate, dissolved and total DMSP were measured for both field and culture samples. Total DMSO was measured for five stations of field sampling (stations 700, 130, 230, 330 and ZG02 on Fig. 1). Samples for DMSP and DMSO were stabilized in acid-cleaned and muffled borosilicate vials by addition of $\mathrm{H}_{2} \mathrm{SO}_{4}(50 \%)$ for later analysis with a gas chromatograph (GC). DMSPd analyses were done on filtered samples, DMSPp analyses on muffled $25 \mathrm{~mm} \mathrm{GF} / \mathrm{F}$ filters and total DMSP and DMSO on unfiltered samples. We adopted the small volume gravity drip filtration procedure recommended by Kiene and Slezak (2006). Gentle filtration of maximum $20 \mathrm{ml}$ was used, only the first $10 \mathrm{ml}$ of filtrate were collected. Additionally, samples for DMS $(30 \mathrm{ml})$ were taken during field sampling and immediately stored in a cold room in acid-cleaned and muffled borosilicate vials sealed with gas tight polytetrafluoroethylene (PTFE) coated silicone septa.

DMSP concentrations were analyzed by GC coupled with a purge-and-trap after alkaline hydrolysis to DMS (Stefels, 2009). Prior to the addition of $\mathrm{NaOH}$, samples were sparged with compressed air, to remove residual dissolved DMS. Concentrations of total DMSO (DMSOt) were analyzed after total DMSP (DMSPt) in the same field samples after acidification and reduction of DMSO into DMS using the $\mathrm{TiCl}_{3}$ method (Kiene and Gerard, 1994).

We used an Agilent 7890B GC equipped with a Flame Ionization Detector (FID) and a Flame Photomultiplier Detector (FPD). The carrier gas $\left(\mathrm{He}, 2 \mathrm{ml} \mathrm{min}^{-1}\right)$ was split between the two detectors $(\sim 30 \%$ for FID, $\sim 70 \%$ for FPD). The FID was kept at $325{ }^{\circ} \mathrm{C}$ with a $\mathrm{H}_{2}$ flow of $57 \mathrm{ml} \mathrm{min}^{-1}$, a synthetic air flow of $500 \mathrm{ml} \mathrm{min}^{-1}$ and a makeup $\left(\mathrm{N}_{2}\right)$ flow of $5 \mathrm{ml} \mathrm{min}{ }^{-1}$. The FPD was kept at $350^{\circ} \mathrm{C}$ with a $\mathrm{H}_{2}$ flow of $72 \mathrm{ml} \mathrm{min}^{-1}$, a synthetic air flow of $72 \mathrm{ml} \mathrm{min}^{-1}$ and a makeup $\left(\mathrm{N}_{2}\right)$ flow of $20 \mathrm{ml} \mathrm{min}{ }^{-1}$. The capillary column was kept at $60^{\circ} \mathrm{C}$.

A primary DMSP stock solution with a concentration in the range of $10^{-3} \mathrm{~mol} \mathrm{~L}^{-1}$ was prepared from a pure DMSP standard (Research Plus) and working solutions with concentrations in the range of $10^{-6}$ or $10^{-7} \mathrm{~mol} \mathrm{~L}^{-1}$ were prepared successively by dilution in Milli-Q water. The same procedure was applied for DMSO and DMS from a $99.9 \%$ pure stock solution (Merck) to obtain working solutions of $10^{-7}-10^{-8} \mathrm{~mol} \mathrm{~L}^{-1}$ and $10^{-5}-10^{-7} \mathrm{~mol} \mathrm{~L}^{-1}$ respectively. Six stan- dards for DMSP, DMSO and DMS were made from these working solutions with concentrations from 0.5 to $300 \mathrm{nmol} \mathrm{L}^{-1}$ for the FPD and from $200 \mathrm{nmol} \mathrm{L}^{-1}$ to $9000 \mathrm{nmol} \mathrm{L}^{-1}$ for the FID in $20 \mathrm{ml}$ serum vials sealed with gas tight PTFE coated silicone septa. Calibration curves were made weekly for the two detectors (or only one depending on expected sample concentrations) by fitting a polynomial curve or a linear regression line for the FPD or FID, respectively. As for samples, standards were analyzed for DMSP prior to DMSO in the same vials. The coefficient of variation was $<10 \%$ between standards. $\mathrm{NaOH}$ pellets were added the day before DMSP analysis in standards and samples (at least $12 \mathrm{~h}$ prior to analysis). Immediately after DMSP analysis, standards and samples were acidified by addition of $2 \mathrm{ml}$ of fuming $\mathrm{HCl}$ and $1 \mathrm{ml}$ of $\mathrm{TiCl}_{3}$ was added before $48 \mathrm{~h}$ of DMSO reduction at room temperature. Before DMSO analysis, standards and samples were neutralized by addition of $1 \mathrm{ml}$ of $\mathrm{NaOH} 12 \mathrm{M}$ in order to avoid injecting acid fumes into the GC.

\subsection{Statistical analyses}

We performed multiple linear regression analyses to assess the effect of biotic and abiotic variables on DMSP and DMSO concentrations. Sea surface salinity (SSS), sea surface temperature (SST), Chl- $a$, suspended particulate matter (SPM) and phosphate $\left(\mathrm{PO}_{4}\right)$ were tested as predictor variables. A set of 55 data (for which all predictor variables data were available) from the nine monitoring sites covering the whole year was used. A multi-collinearity test was carried out giving Variance Inflation Factor of maximum 2.5, under the standard limit value of 10 (Miles, 2014). A Breusch-Pagan test was performed that confirm the homoscedasticity of residuals (LM $<$ LMcrit; $\mathrm{p}$-value $=0.133$; alpha $=0.05$ ). However, we had to reject the null hypothesis that the residuals are normally distributed according to Shapiro-Wilk $(\mathrm{W}<\mathrm{Wcrit}$; $<0.0001$; alpha $=0.05)$ and Lilliefors tests $(\mathrm{D}<$ Dcrit; $\mathrm{p}=0.009$; alpha $=0.05)$. As our variables contain $>40$ data points (Pallant, 2007), we assumed that our regression was still robust despite this violation from the assumptions (Elliott and Woodward, 2007).

\section{Results and discussion}

\subsection{Seasonal and spatial evolution of abiotic parameters}

Daily averaged PAR showed typical seasonal variability with winter values around $70 \mu \mathrm{E} \mathrm{m}^{-2} \mathrm{~s}^{-1}$ and maximal values around $710 \mu \mathrm{E} \mathrm{m}^{-2} \mathrm{~s}^{-1}$ in summer (Fig. 2a). SST averaged for the nine sampled stations in the $\mathrm{BCZ}$ showed a clear seasonal pattern with values varying between $6.9^{\circ} \mathrm{C}$ in winter and $19.8^{\circ} \mathrm{C}$ in summer with low spatial variability (Fig. 2b). Average SSS for the nine sampled stations varied between 31.3 and 33.9 along the seasonal cycle with maximal values in winter and minimal values in late spring-early summer (Fig. 2c). Spatial distribution of SSS was characterized by a general increase from near-shore to offshore stations with annual averaged salinity varying from 30.7 in most coastal station (700) and 34.9 in most offshore station (ZG02) (Fig. 1).

Nutrients and SPM varied broadly over space and time (Fig. 3). Spatially averaged dissolved silica (DSi) (Fig. 3a) and dissolved inorganic nitrogen (DIN) (Fig. 3b) reached their highest concentrations in winter (mid-February) and lowest values in spring due to phytoplankton uptake (Rousseau et al., 2006). Spatial variability of DIN and DSi concentration was particularly marked in winter with the highest differences between minimal and maximal values (Fig. 3a, b). In summer, nutrient concentrations showed different patterns depending on the location, with a strong divergence between median and average 
a.

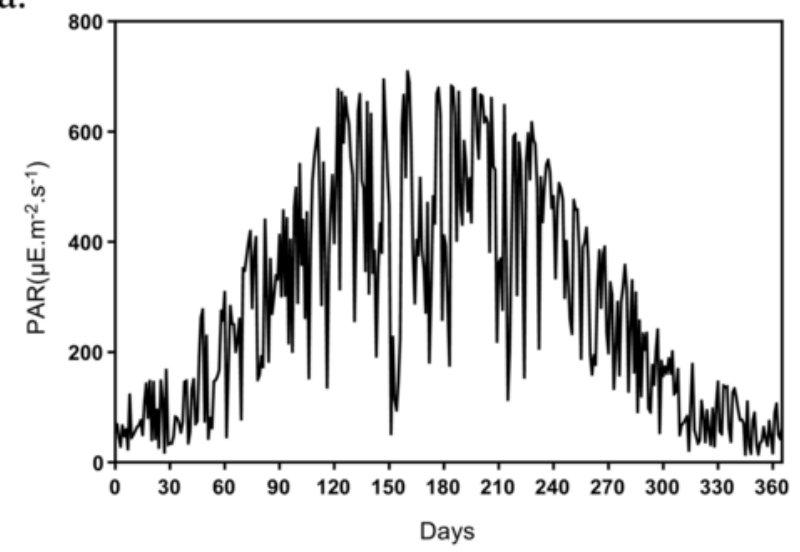

b.

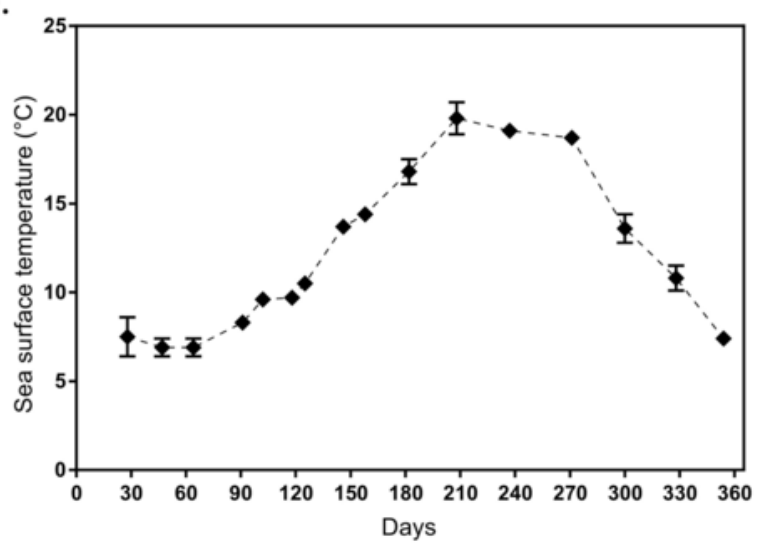

c.

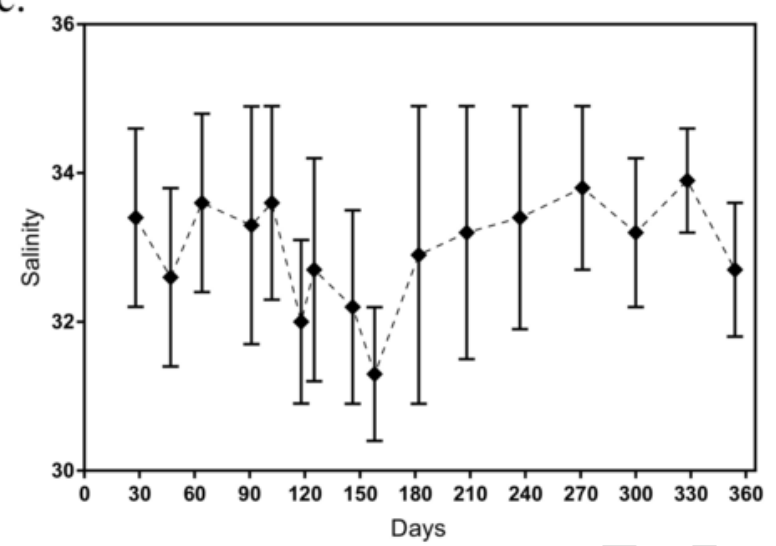

Fig. 2. Seasonal evolution of (a) daily-averaged Photosynthetic Active Radiation (PAR), (b) sea surface temperature (SST) and (c) salinity averaged for the nine stations (refer to Fig. 1) sampled in the Belgian Coastal Zone in 2016.

values. The seasonal evolution of spatially averaged $\mathrm{PO}_{4}$ showed similar patterns with maximal concentration in winter and minimal concentration in spring (Fig. 3c). Summer $\mathrm{PO}_{4}$ values were similar to the winter ones but showed larger spatial variability as indicated by the min-max difference (Fig. 3c). Average SPM varied from highest values in winter and lowest values in summer (Fig. 3d). In winter, the spatial gradients of SPM were stronger as indicated by the high range of min-max values (Fig. 3d). The highest SPM concentrations were observed in January $\left(190 \mathrm{mg} \mathrm{L}^{-1}\right)$ and December $2016\left(290 \mathrm{mg} \mathrm{L}^{-1}\right)$ at station 700 .
For each nutrient, winter concentrations decreased from near-shore stations (e.g. 700, 710) to offshore stations (e.g. ZG02) with maximum concentrations at station 700 because of its proximity with the Scheldt estuary (Fig. 4a, b). Winter concentration of DIN, DSi and $\mathrm{PO}_{4}$ decreased from respectively $40-55,20-30$ and $1 \mu \mathrm{mol} \mathrm{L}{ }^{-1}$ at station 700 to 15,6 and $0.5 \mu \mathrm{mol} \mathrm{L}{ }^{-1}$ at the station farthest from the mouth of the Scheldt estuary (ZG02) (Fig. 4a, b). SPM also decreased from near-shore to off-shore stations (Fig. 4c, d).

\subsection{Seasonal evolution of Chl-a and $D M S(P, O)$ concentration}

As previously described (e.g. Lancelot et al., 2007), seasonal evolution of phytoplankton bloom in the area is characterized by a succession of three blooms (early spring diatoms in February, Phaeocystis colony bloom in April-May and summer diatom from July/August to end of September) with Chl-a maximal concentration of $36 \mu \mathrm{g} \mathrm{L}^{-1}$ for the different sampled stations in spring (Fig. 5a). Seasonal evolution of DMSPp (Fig. 5b) followed the same seasonal pattern than Chl- $a$ concentration and was then characterized by a huge peak with concentration up to $1740 \mathrm{nmol} \mathrm{L}^{-1}$ in April-May during Phaeocystis bloom and two relatively low peaks with average DMSPp concentration around 45 and $50 \mathrm{nmol} \mathrm{L}^{-1}$ in early spring and summer (Fig. $5 b)$ associated to diatom blooms. Higher spatial variability was measured in April-May with marked differences between minimal and maximal values and average and median values (Fig. 5b). DMSPd showed a similar seasonal pattern but with concentrations lower than $50 \mathrm{nmol} \mathrm{L}^{-1}$ around the year (Fig. 5c). In 1989, in the SNS, Turner et al. (1996) reported averaged concentrations of around $200 \mathrm{nmol} \mathrm{L}^{-1}$ for both DMSPp and DMSPd in May with local maxima of 450 and $600 \mathrm{nmol} \mathrm{L}^{-1}$ for DMSPp and DMSPd, respectively. Our DMSP concentrations are generally higher than those of Turner et al. (1996) and the relative importance of DMSPp and DMSPd were opposite with a larger part of DMSPp than DMSPd in our measurements. This difference could result from the filtration procedure, that, in the past, tented to overestimate DMSPd and underestimate DMSPp (Kiene and Slezak, 2006). The total quantity of DMSP (DMSPp + DMSPd) will also largely vary depending on the location of the sampling station and the magnitude of the phytoplankton bloom, in particular the Phaeocystis bloom (Figs. 5; 6). The Turner et al. (1996) data were collected about $75 \mathrm{~km}$ from the $\mathrm{BCZ}$ coastline, while our sampling stations were within $20 \mathrm{~km}$ of the coastline. Breton et al. (2006) pointed out a significant interannual variability in the magnitude of Phaeocystis blooms in the $\mathrm{BCZ}$ due to the combined effects of hydro-climatic variability and human activities via the Scheldt nutrient loads. The DMSP values we report were also higher than those reported in the deeper and seasonally stratified northern North Sea, with maximum DMSPp values of $70 \mathrm{nmol} \mathrm{L}{ }^{-1}$ reported during a bloom of coccolithophores (Archer et al., 2002). However, the maximum DMSP values we report converge with those reported by van Duyl et al. (1998) in the Wadden Sea (maximum DMSPp of $\left.1650 \mathrm{nmol} \mathrm{L}^{-1}\right)$. Overall, these results confirm that shallow productive near-shore coastal areas where high DMSP producing taxa such Phaeocystis occur can show DMS(P) values an order of magnitude higher than more open oceanic deeper and less productive waters, even within a given continental shelf system such as the North Sea.

DMS (Fig. 5d) followed the same pattern than DMSP with spatially averaged concentration of $180 \mathrm{nmol} \mathrm{L}^{-1}$ in May (with local maximum up to $250 \mathrm{nmol} \mathrm{L}^{-1}$ ). The timing of the DMS peak was closely linked to the DMSP peak suggesting that DMS was formed from the transformation (cleavage) of DMSP (mainly during the Phaeocystis bloom), a typical interpretation of seasonal DMS(P) cycles (Kwint and Kramer, 1996), in line with the general understanding of DMSP-DMS dynamics (Stefels et al., 2007), based for instance 
a.

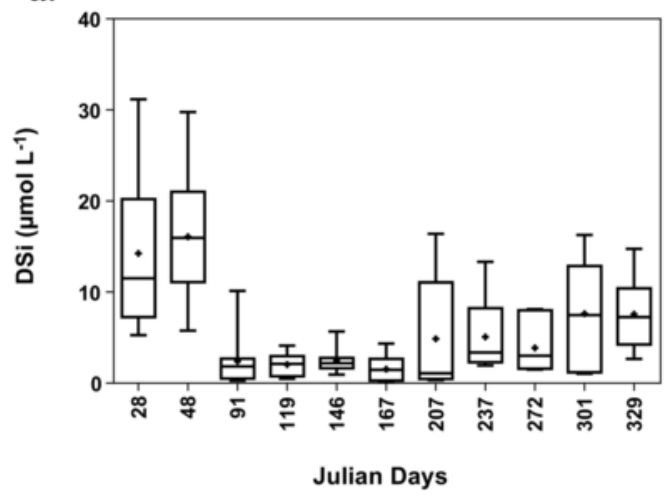

c.

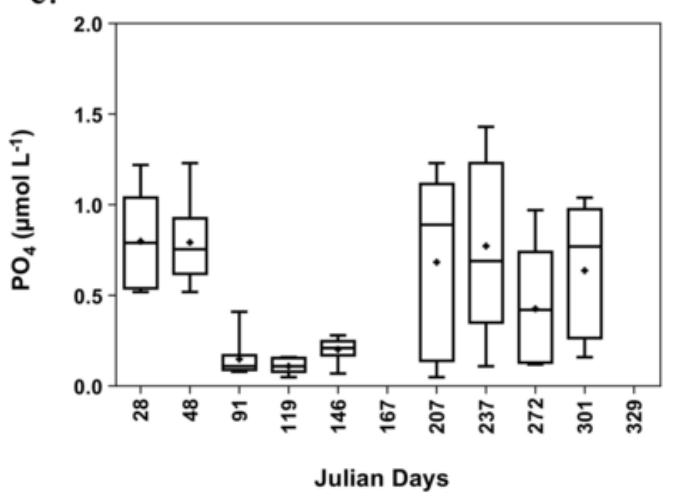

b.

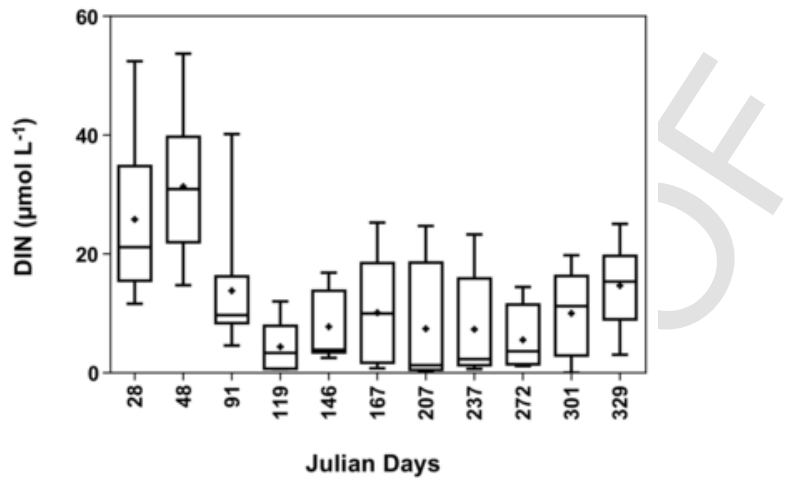

d.

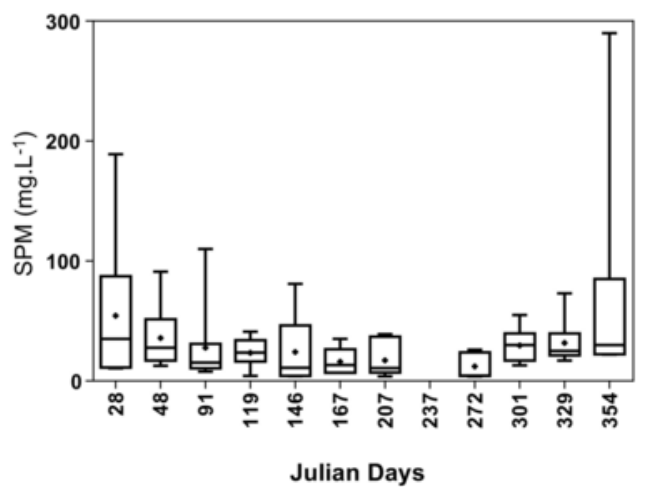

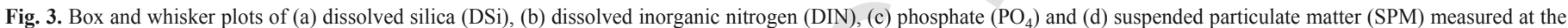

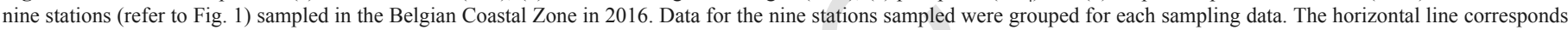
to the median, the cross to the arithmetic average, the box to the interquartile range, error bars to the minimal and maximal values.

on the study of sulfur isotopes of DMSP and DMS (Kiene and Linn, 2000b). Phaeocystis is known for its high DMSP production (Keller et al., 1989) and DMSP-lyase activity (Stefels et al., 1996) than can cleave DMSP into DMS. Turner et al. (1996) reported a maximum monthly and spatially averaged surface DMS concentration of $55 \mathrm{nmol} \mathrm{L}^{-1}$ in May 1989 in the SNS due to an extensive bloom of Phaeocystis. Our maximum spatially averaged DMS concentration of $129 \mathrm{nmol} \mathrm{L}^{-1}$ also occurred in May, and was higher because our stations were more in-shore than those of Turner et al. (1996). Turner et al. (1996) found locally concentrations up to $311 \mathrm{nmol} \mathrm{L}^{-1}$ during that same month, which is in good agreement with our maximum of $268 \mathrm{nmol} \mathrm{L}^{-1}$ at station 120 in early May. As previously shown by van Duyl et al. (1998), the DMS peak coincided with the Phaeocystis bloom and DMSP maxima rather than following it, as a result of the fast growth of DMS-consuming bacteria after the bloom, and emission to the atmosphere preventing accumulation of DMS in water. The maximum DMS concentrations we report $\left(255 \mathrm{nmol} \mathrm{L}^{-1}\right)$ were similar to maximum values reported by other studies in coastal near-shore areas of the North Sea (Kwint and Kramer, 1996; van Duyl et al., 1998) and were higher than those reported in the deeper and seasonally stratified northern North Sea, with maximum DMS values of $5 \mathrm{nmol} \mathrm{L}^{-1}$ reported during a bloom of coccolithophores (Archer et al., 2002). Overall, the DMS maximum concentrations in the near-shore coastal areas of the North Sea are one to two orders of magnitude higher than the seasonal maxima typical of open oceanic waters, as compiled and reviewed by Lana et al. (2011).

As a general pattern, DMSOt showed a similar seasonal evolution than Chl- $a$ and DMSP with maximal averaged value of $250 \mathrm{nmol} \mathrm{L}^{-1}$ (and local maximum up to $600 \mathrm{nmol} \mathrm{L}^{-1}$ ) associated to the spring bloom of Phaeocystis (Fig. 5e). However, DMSOt slightly increased at the end of the year but not associated to similar increase of DMSPp or DMSPd (Fig. 5b, c). For DMSO, the highest spatial variability was measured in December with marked differences between minimal and maximal values (Fig. 5e). Based on these measurements, average DMSPt:DMSOt ratio varied between 0.7 and 2.5 during (spring and summer) diatom blooms and increased up 7 during the Phaeocystis bloom. Values computed during diatom blooms were lower than the ratio generally measured for particulate fractions in phytoplankton pure culture (between 1.1 and 12.1 for diatoms; Hatton and Wilson, 2007). We can thus expect than most of the DMSO measured in the area was in dissolved phase (excepted during the Phaeocystis bloom) in particular in winter when DMSO can reach high values (Fig. 5e) and Chl- $a$ and DMSPp were low (Fig. 5a, b). The relative importance of particulate and dissolved fractions varies between DMSP and DMSO and seasonally. Generally, DMSPd is very low compared to DMSPp while DMSOd dominates DMSO pool and can exceed concentration of both DMS and DMSPd in euphotic waters (Hatton and Wilson, 2007). Simó et al. (1998) reported DMSOp and DMSOd concentrations for North Sea samples containing Phaeocystis (UK coast, in June) of respectively 16 and $25 \mathrm{nmol} \mathrm{L}^{-1}$. This is lower than our concentrations but their samples were probably taken at the end of Phaeocystis bloom, while our samples covered the whole bloom period. For August in the same area, they reported DMSOp and DMSOd concentrations of respectively 2.7 and $2.3 \mathrm{nmol} \mathrm{L}^{-1}$ for seawater samples containing diatoms and dinoflagellates. Hatton et al. (1996) reported DMSOd concentrations ranging between 0.5 and $17.5 \mathrm{nmol} \mathrm{L}^{-1}$ for coastal and shelf waters in the North Sea in June. 
a.

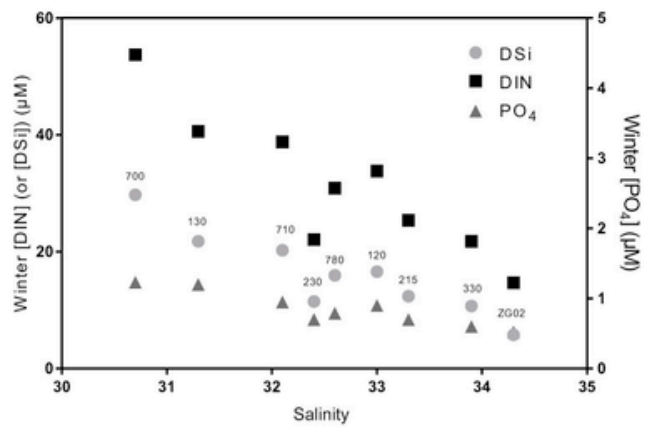

c.

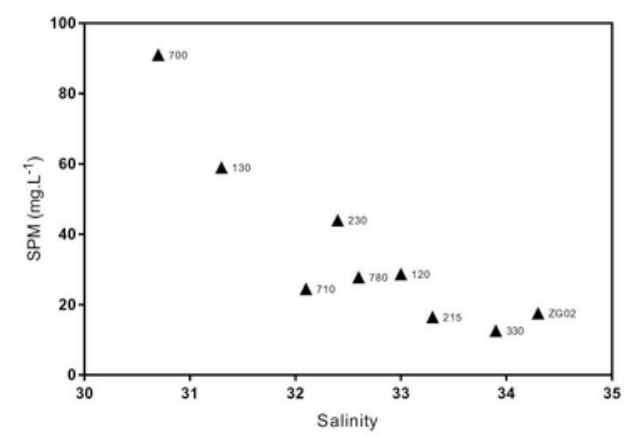

b.

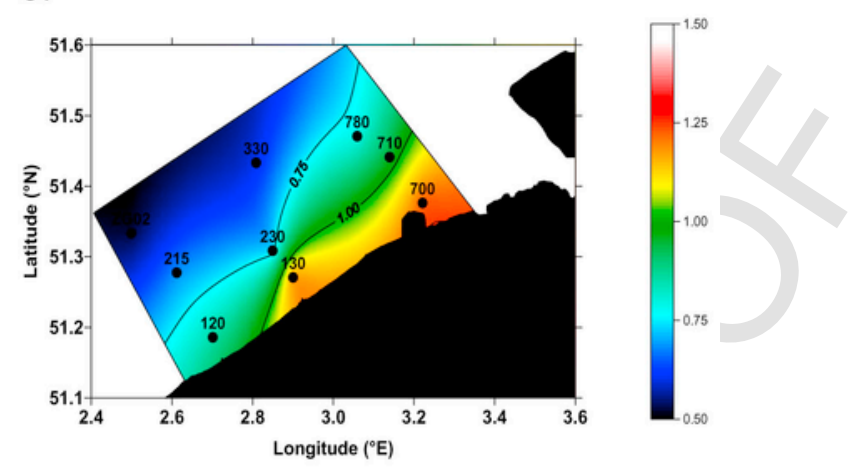

d.

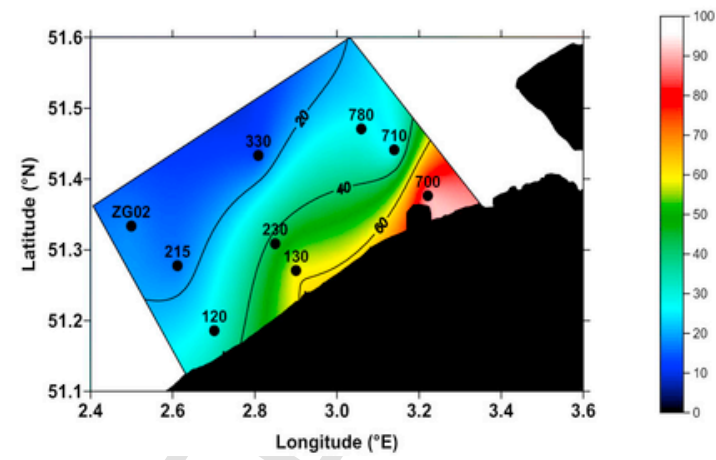

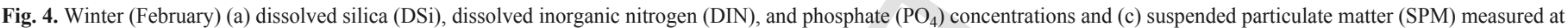
the nine stations sampled in the Belgian Coastal Zone in 2016 as function of salinity. Spatial plots of winter $(\mathrm{b}) \mathrm{PO}_{4}(\mu \mathrm{M})$ and $\left.(\mathrm{d}) \mathrm{SPM}_{(\mathrm{mg} \mathrm{L}}^{-1}\right) \mathrm{concentration}$

\subsection{Spatial variations of Chl-a and $D M S(P, O)$ concentrations}

Annual averaged concentrations of Chl- $a$ computed for each sampling station decreased with increasing salinity (and decreasing nutrient concentrations) (Fig. 6a). However, two decreasing patterns can be observed (Fig. 6a) with stations $(700,710,780)$ under the direct influence of the Scheldt (and high SPM; Fig. 4b) characterized by lower Chl- $a$ concentration than the other two transects at similar or lower salinity values (and higher nutrient concentrations; Fig. 4a). Maximum Chl- $a$ concentrations were measured at station 130 and lower concentration at station ZG02. Total DMSP showed a similar pattern with low values in particular for the station 700 and 710 . The evolution of DMSPt as a function of salinity for the other stations was less clear than for Chl- $a$ (Fig. 6b). Total DMSO concentrations were similar for most of the stations, except for station 700 that was characterized by a concentration three times higher (Fig. 6c). This very high DMSO concentration could be related to the high SPM concentration measured at this station (Fig. 4b, d) suggesting that in very near-shore stations, part of the DMSO measured could be linked to the resuspension of sediment. DMS spatial variability seemed to follow the DMSP concentration (Fig. 6d).

Seasonal evolution of Chl- $a$ and DMS(P,O) (Fig. 7) measured at five stations chosen to cover both near-offshore gradient and a longitudinal gradient from station 700 (close to the Scheldt estuary), to the most "marine" station (ZG02) reveals an important spatial variability mainly during the spring bloom in April-May. Most of the stations were characterized by a marked seasonal variability of Chl- $a$ with maximal concentration measured in spring varying from 7 to $35 \mu \mathrm{g} \mathrm{L}^{-1}$ along a coastal-offshore gradient (Fig. 7a). On the contrary, Chl- $a$ concentration measured at station 700 stayed approxi- mately constant throughout the year. In response to Chl- $a$ concentration, DMSP also showed marked seasonal and spatial variability with spring maximal value varying from 160 to $1750 \mathrm{nmol} \mathrm{L}^{-1}$ (Fig. 7b). Apart from station 700, other stations were not clearly differentiated in terms of DMSOt concentrations (Fig. 7c). Station 700 had high concentrations of DMSOt, probably because of an accumulation of DMS in the suspended organic matter where it could be oxidized into DMSO (Hatton, 2002). This is particularly noticeable in December when SPM (Fig. 3d) and DMSOt (Fig. 7c) are very high $\left(290 \mathrm{mg} \mathrm{L}^{-1}\right.$ and $500 \mathrm{nmol} \mathrm{L}^{-1}$, respectively). DMS concentration (Fig. 7d) is not exactly related to DMSP but stations characterized by high DMSP values are also characterized by high DMS concentration and lowest concentrations are measured at station 700 as for DMSP (Fig. 7a).

\subsection{Drivers of $D M S(P, O)$ variability in the $S N S$}

To investigate whether the observed variation in $\operatorname{DMS}(\mathrm{P}, \mathrm{O})$ could be explained by the effect of the measured abiotic and biotic variables, multiple-regression analyses were performed (Table 1). DMSP was strongly correlated to Chl- $a(\operatorname{coef}=62.29, \mathrm{t}=11.07, \mathrm{p} \ll 0.001)$ (Table 1). The other variables tested were not significantly correlated to DMSP concentration (Table 1). DMSO was not significantly related to any abiotic or biotic factors tested (not shown).

We compared DMSP computed for the whole data set from the linear regression with Chl- $a$ (DMSPp $\left(\mathrm{nmol} \mathrm{L}^{-1}\right)=48.34 * \mathrm{Chl}-a$ $\left.\left(\mu \mathrm{g} \mathrm{L}^{-1}\right), \mathrm{r}^{2}=0.74, \mathrm{p} \ll 0.001\right)$ with the initial DMSP data. The regression model tends to overestimate DMSP except during the Phaeocystis bloom (Fig. 8a). The relationship deduced from field measurements is highly influenced by the Phaeocystis bloom and is not adapted to estimate neither DMSP linked to spring and summer 


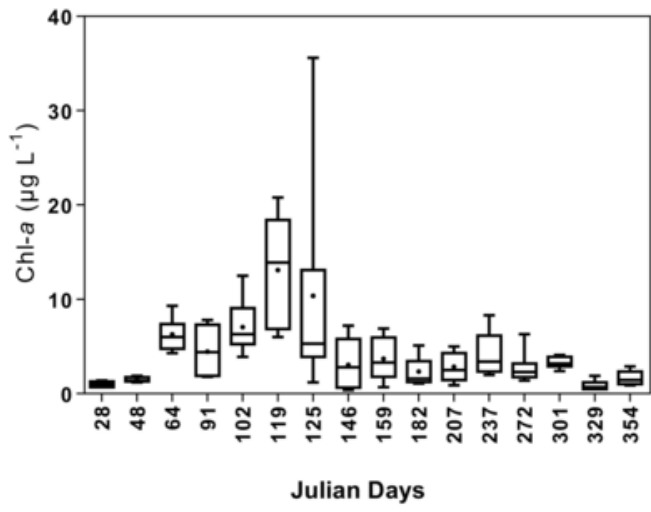

c.

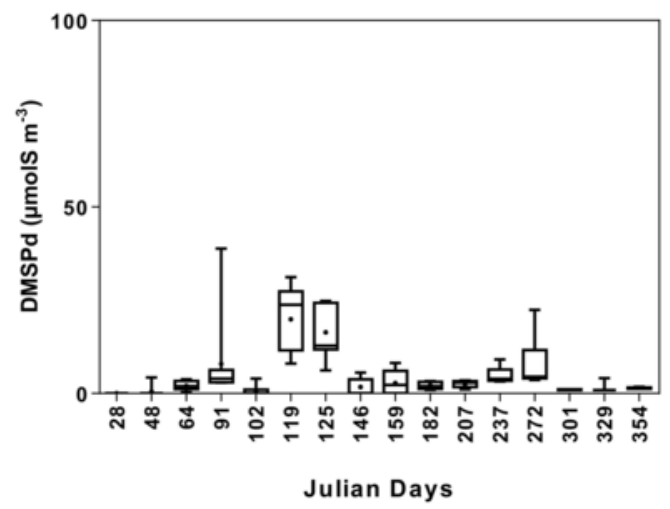

e.

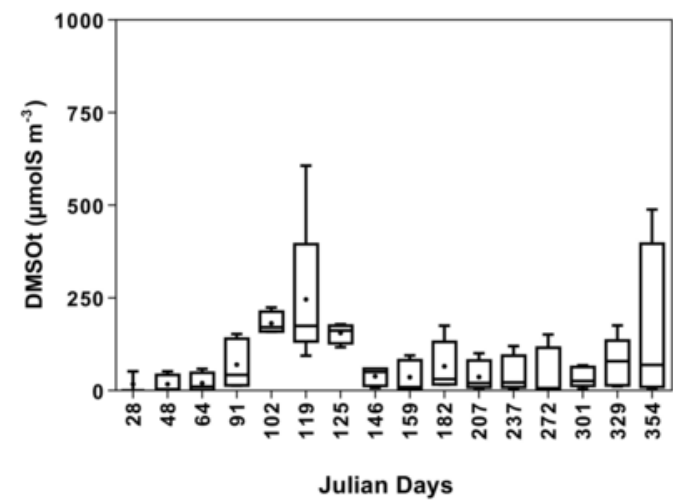

b.

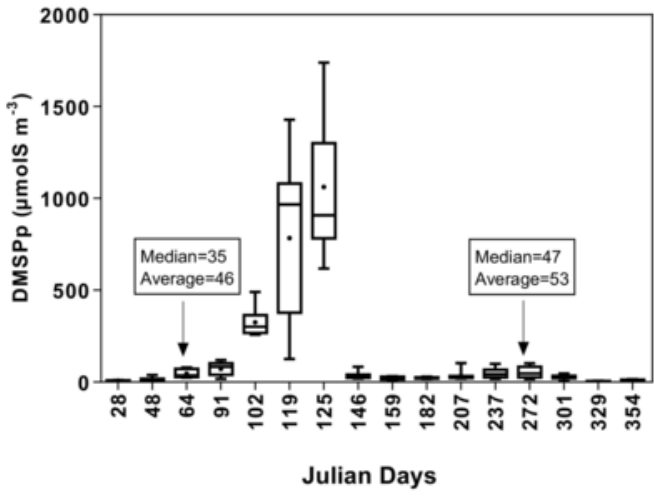

d.

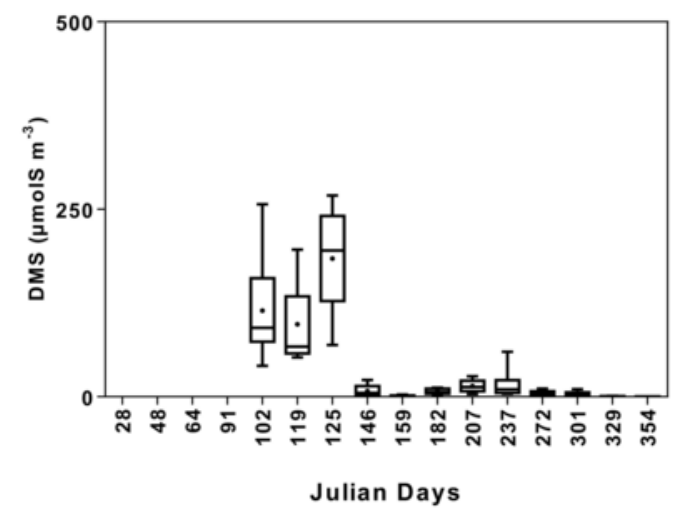

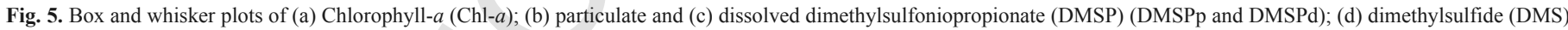

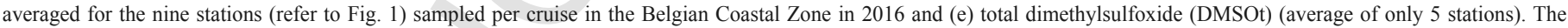
horizontal line corresponds to the median, the cross to the arithmetic average, the box to the interquartile range, error bars to the minimal and maximal values.

diatom blooms nor winter DMSP values. The magnitude of the modelled DMSP peak linked to the Phaeocystis bloom is generally underestimated compared to measurements (Fig. 8a). Despite the importance of phytoplankton biomass (captured by Chl- $a$ ) for the DMSP concentration, this kind of simple relationship between DMSP and Chl- $a$ is not sufficiently robust to correctly describe seasonal and spatial variability of DMSP and, by extension, to estimate DMS emissions, as also shown by Gypens et al. (2014).

\subsection{Phytoplankton composition and DMSP concentration}

Phytoplankton biomass and composition at station 330 (Fig. 9) were similar to previous studies at the same station (Rousseau et al., 2002), with a recurrent pattern of blooms of three diatom communities and Phaeocystis. The first diatom community (February-March, day 60 to 90 ; community 1) is mainly composed of colonial diatoms (including Skeletonema costatum, Thalassiosira spp., Thalassionema 
a.

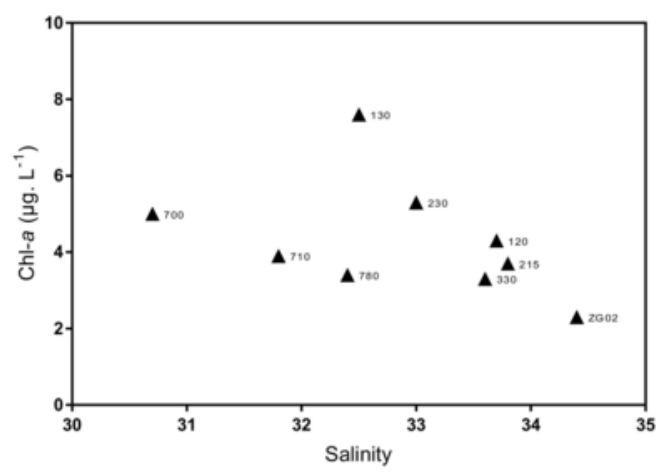

c.

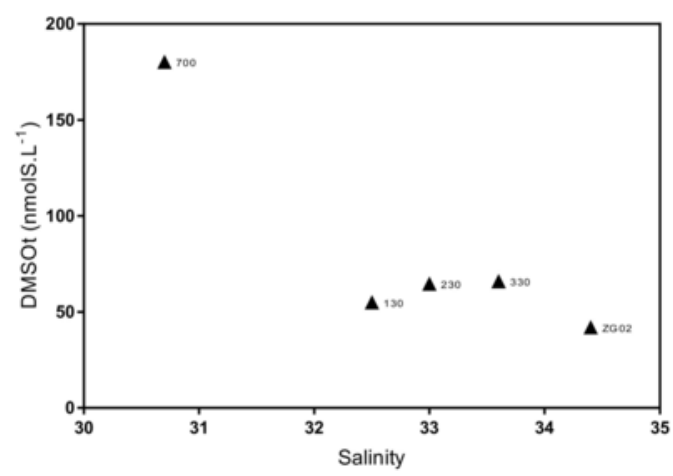

b.

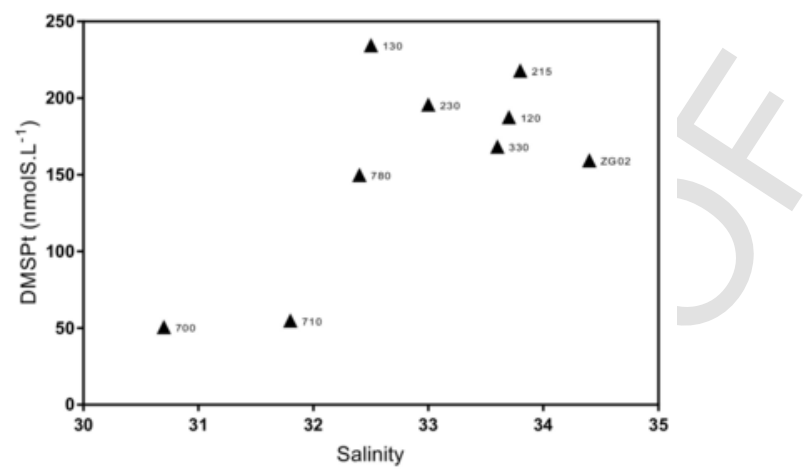

d.

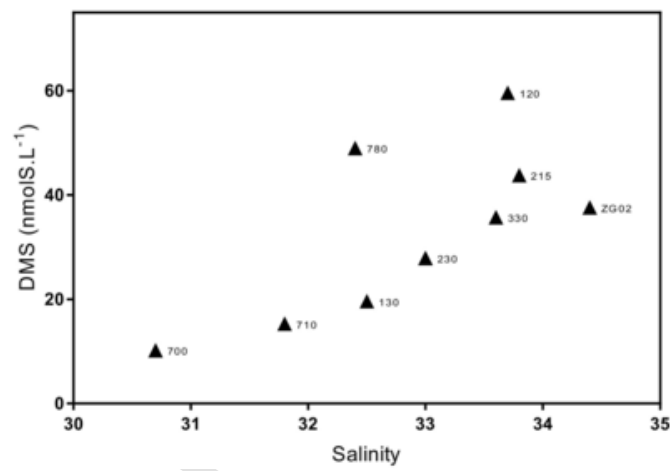

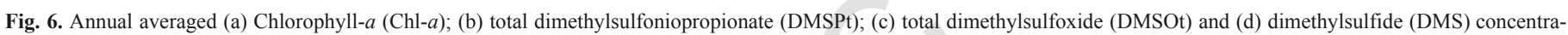
tions measured at the nine stations (refer to Fig. 1) sampled in the Belgian Coastal Zone in 2016 as function of salinity.

nitzschioides, Asterionella spp., Biddulphia spp., Nitzschia spp.) and Ditylum brightwellii in 2016 (Fig. 9a). In term of biomass, Ditylum brightwellii is dominant in February-March in 2016 (Fig. 9b). Some of these species co-occurred with the second diatom community of Chaetoceros spp. (day 102; Fig. 9a). The onset of Phaeocystis is associated to the Chaetoceros community in early March-mid April (day 102 to 125; Fig. 9c; Rousseau et al., 2002). Pseudo-Nitzschia delicatissima cells are frequent on the surface of Phaeocystis colonies and is one of the only diatom observed during the Phaeocystis bloom in 2016 (Fig. 9a). The third diatom community composed of large-sized diatoms (Rousseau et al., 2002) as Guinardia spp. appeared at the end of the Phaeocystis bloom and dominates the phytoplankton biomass in June-July (day 180 to 207; Fig. 9c) after a short period of very clear water in end of May-early June. From August to October species from community 1 were blooming again in addition of some new species like Eucampia zodiacus. Some dinoflagellates were also observed in July (day 237; Fig. 9c).

Carbon to Chl- $a$ ratio (C:Chl- $a$ ) ranged between 10 (late October) and 388 at the end of the Phaeocystis bloom in May (not shown). This ratio could be comprised between 10 and 300 (Cloern and Jassby, 1995); it is taxon-dependent and varies seasonally with nutrient depletion and limitation. Spring diatoms have low C:Chl- $a$ (20-40) compared to summer diatoms when nutrients are exhausted (Steele and Baird, 1962; Welschmeyer and Lorenzen, 1984). Dinoflagellates and Phaeocystis spp. have high C:Chl-a (Eppley et al., 1977; Verity et al., 1991).

Following the phytoplankton composition changes, DMSPp:Chl- $a$ and DMSPp:C ratios varied along the seasonal cycle (Fig. 10).
Higher values are associated to the Phaeocystis bloom and this was particularly marked for the DMSPp:Chl- $a$ ratio at the end of the bloom (Fig. 10). DMSPp:Chl- $a$ and DMSPp:C ratios were lower for diatom blooms, particularly in summer during the bloom of Guinardia (day 210; Figs. 9c, 10). An increased ratio was observed in association with dinoflagellates in summer (day 240; Figs. 9c, 10). These results ware in accordance with measurements made on a few key-species of the studied area in batch cultures and with the data compiled by Keller et al. (1989) and Stefels et al. (2007) (Table 2). As a general pattern, diatoms were on average characterized by a DMSPp:Chl- $a$ around $4 \pm 6 \mathrm{mmolS}$ gChl- $a^{-1}$ (Table 2; Stefels et al., 2007). However, some species such as Skeletonema costatum blooming in early spring in the area has a higher DMSP quota. DMSP quota by Guinardia spp. was very low in pure cultures (Table 2) and can explain the low DMSPp:Chl- $a$ and DMSPp:C ratios observed in the area in summer (Fig. 10).

Two different DMSPp versus Chl- $a$ correlations could be discriminated, one for all diatoms and another one for only Phaeocystis colonies. These correlations depict the taxon-dependency of DMSPp production with a high production by Phaeocystis blooming in April-May (DMSPp $\left(\mathrm{nmol} \mathrm{L}^{-1}\right)=58.17 * \mathrm{Chl}-a\left(\mu \mathrm{g} \mathrm{L}^{-1}\right), \mathrm{r}^{2}=0.78$, $\mathrm{p} \ll 0.001$ ) and a low DMSP production by diatoms (DMSPp

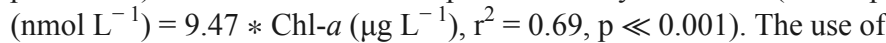
these specific DMSPpChl- $a$ relationships allows a better fit of modelled DMSP compared to observations (Fig. 8b). Consequently, empirical relationship used in global models to estimate DMSP based on Chl- $a$ should, at least, consider two separate DMSP-Chl- $a$ relationships for diatoms and non-diatoms. 
a.

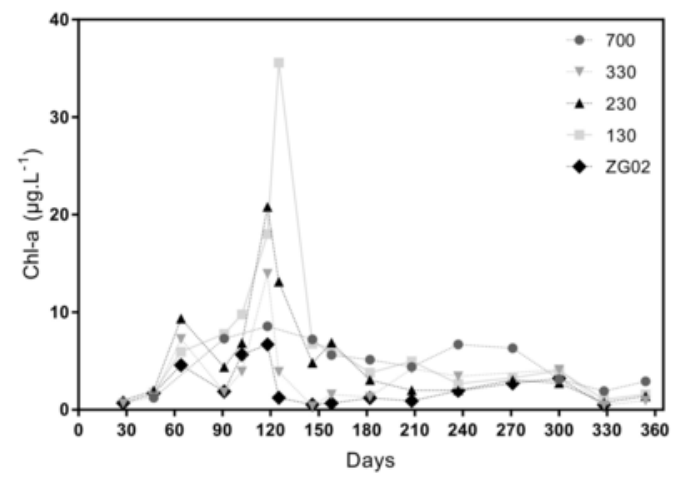

c.

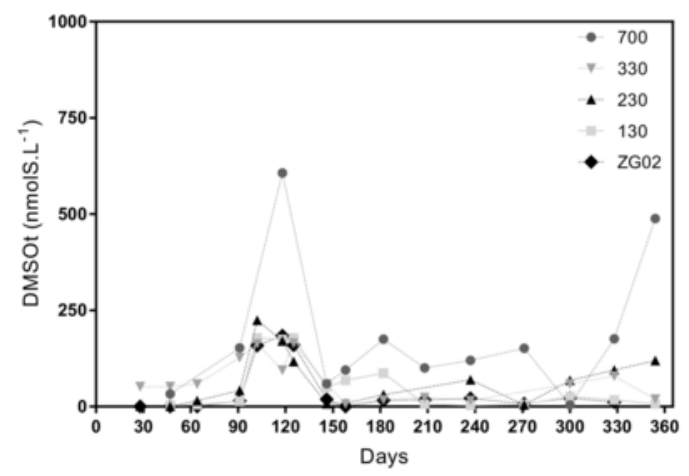

b.

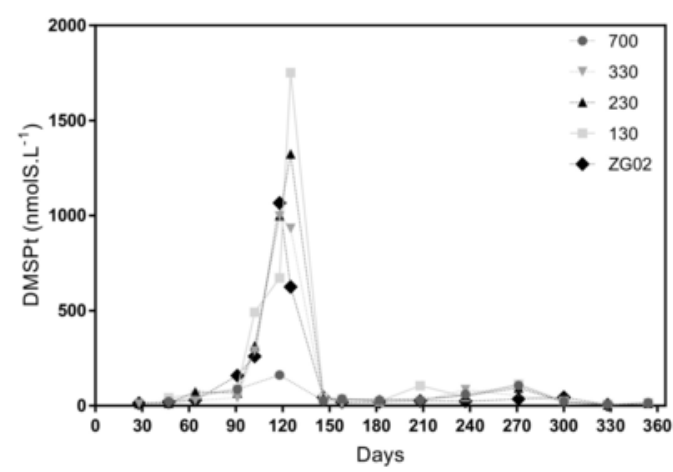

d.

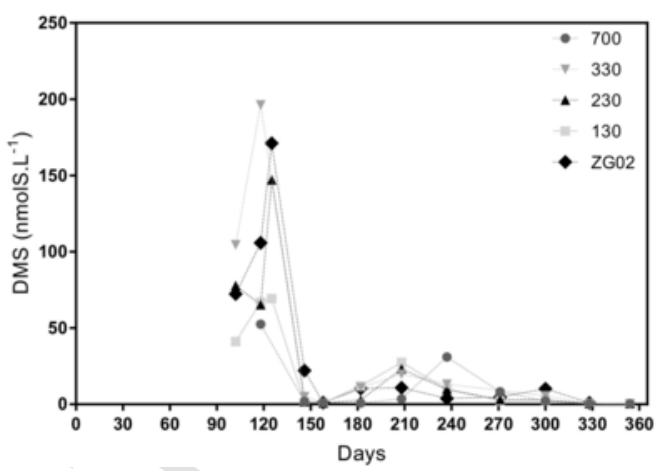

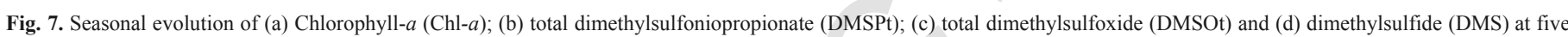
stations in the Belgian Coastal Zone in 2016.

Table 1

Multiple-regression analysis of effects of sea surface salinity (SSS), sea surface temperature (SST, $\left.{ }^{\circ} \mathrm{C}\right), \mathrm{Chl}-a\left(\mu \mathrm{g} \mathrm{L}^{-1}\right)$, Suspended particulate matter $\left(\mathrm{SPM}, \mathrm{mg} \mathrm{L}^{-1}\right)$ and $\mathrm{PO}_{4}$ $\left(\mu \mathrm{mol} \mathrm{L}{ }^{-1}\right)$ on the dependent variable DMSP $\left(\mathrm{nmol} \mathrm{L}^{-1}\right)$. Only data for which all measurements were available were used $(\mathrm{n}=55)$.

\begin{tabular}{llll}
\hline & Parameter estimates & $\mathrm{t}$ & $\mathrm{p}$ \\
\hline Intercept & -1201.38 & -1.38 & 0.17 \\
SSS & 36.97 & 1.48 & 0.14 \\
SST & -8.65 & -1.79 & 0.08 \\
Chl- $a$ & 62.29 & 11.07 & $6.10^{-15}$ \\
SPM & -1.79 & -1.28 & 0.21 \\
$\mathrm{PO}_{4}$ & 41.19 & 0.59 & 0.59 \\
\hline
\end{tabular}

\section{Conclusions}

In the $\mathrm{BCZ}, \mathrm{DMS}(\mathrm{P}, \mathrm{O})$ dynamics were particularly marked by a strong seasonality driven by the phytoplankton succession, during which low DMS $(\mathrm{P}, \mathrm{O})$ producers (diatoms) alternated with high DMS(P,O) producers (Phaeocystis globosa and dinoflagellates). In addition, very marked spatial variability of $\operatorname{DMS}(\mathrm{P}, \mathrm{O})$ was also observed at very small scale as the stations were $<20 \mathrm{~km}$ apart. This is due to the presence of the Scheldt estuary influencing both DMSP and DMSO concentrations, because of the influence on phytoplankton biomass of the estuarine inputs of inorganic nutrients and total suspended matter. Overall, maximum DMSP ${ }_{\mathrm{t}}$ and DMS values associated to the Phaeocystis bloom in this near-shore shallow and very productive coastal environment (1740 and $250 \mathrm{nmol} \mathrm{L}^{-1}$, respectively) were one to two orders of magnitude higher than those typically encountered in open oceanic waters, as well as those in the deeper stratified northern North Sea even during blooms of high DMSP producing coccolithophorids.

\section{Uncited reference}

Wolfe et al., 2002

\section{Acknowledgements}

We are grateful to the crew of the $R V$ Simon Stevin for assistance during the cruises, to André Cattrijsse and Jonas Mortelmans (VLIZ) for organizing the schedule of cruises, and to two anonymous reviewers for constructive comments on a previous version of the manuscript. The GC was acquired with funds from the Fonds National de la Recherche Scientifique (FNRS) (2.4.637.10). NG received financial support from the Fonds David et Alice Van Buuren. GS and CR have a $\mathrm{PhD}$ grant from the FRIA (Fund for Research Training in Industry and Agriculture, FNRS). AVB is a senior research associate at the FNRS. 
a.

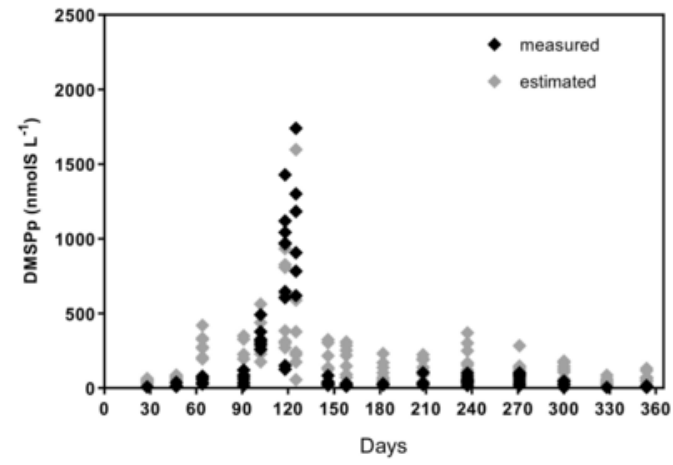

b.

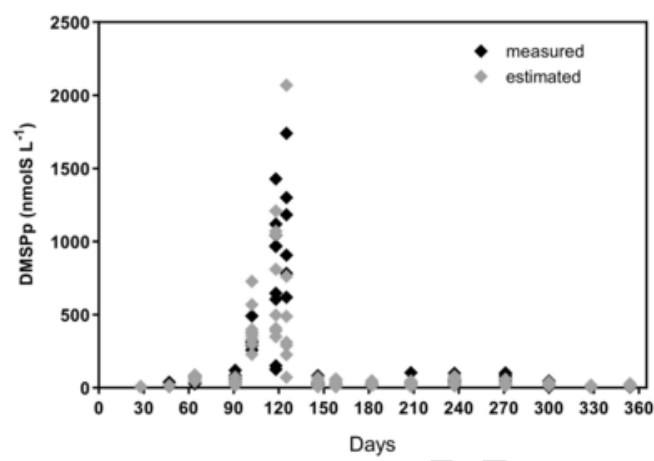

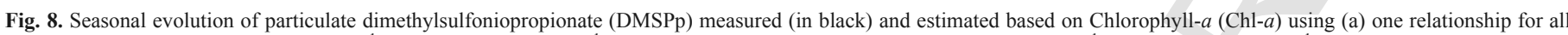

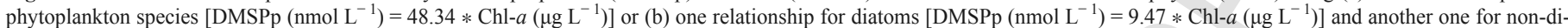
atoms [DMSPp $\left.\left(\mathrm{nmol} \mathrm{L}^{-1}\right)=58.17 * \mathrm{Chl}-a\left(\mu \mathrm{g} \mathrm{L}^{-1}\right)\right]$.

a.

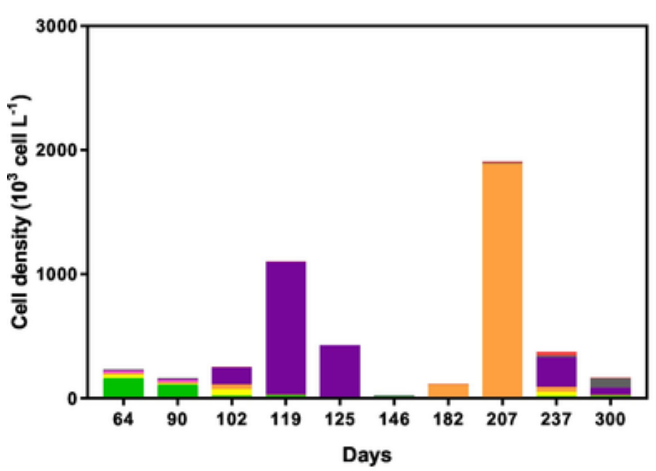

c.

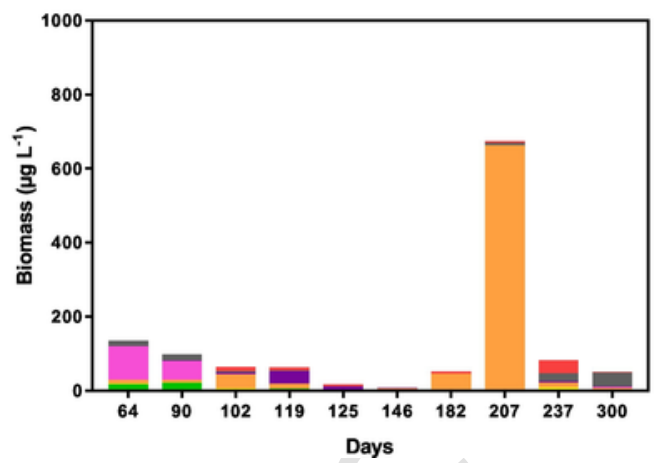

b.

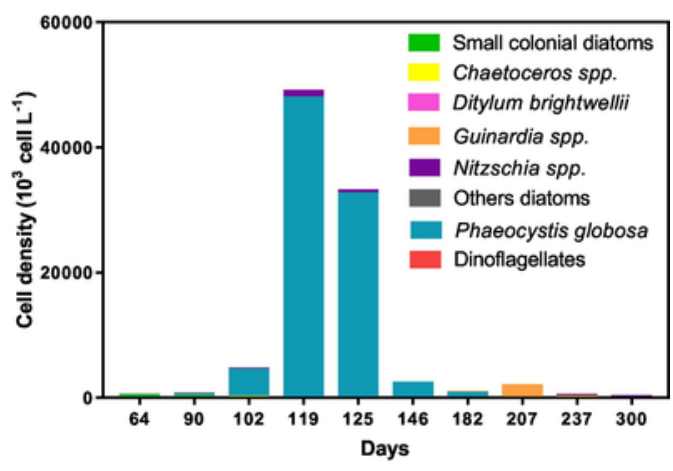

d.

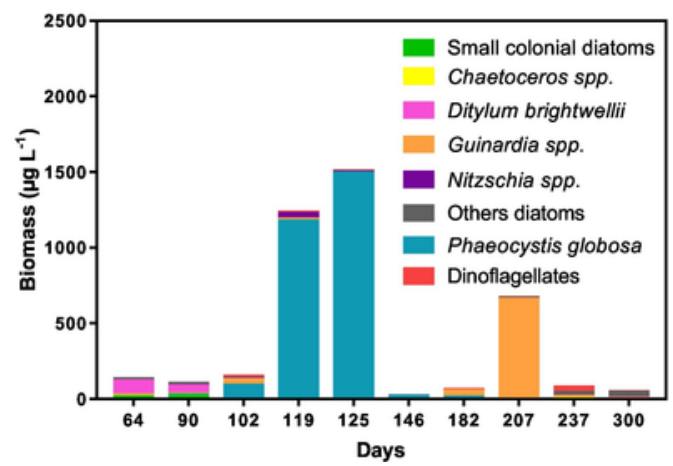

Fig. 9. Seasonal variation of phytoplankton cell density $\left(10^{3} \mathrm{~L}^{-1}\right)(\mathrm{a}, \mathrm{b})$ and biomass $\left(\mu \mathrm{g} \mathrm{L} \mathrm{L}^{-1}\right)(\mathrm{c}, \mathrm{d})$ at station 330 during the year 2016 with (b, d) and without $(\mathrm{a}, \mathrm{c})$ taking account for Phaeocystis colonies. 


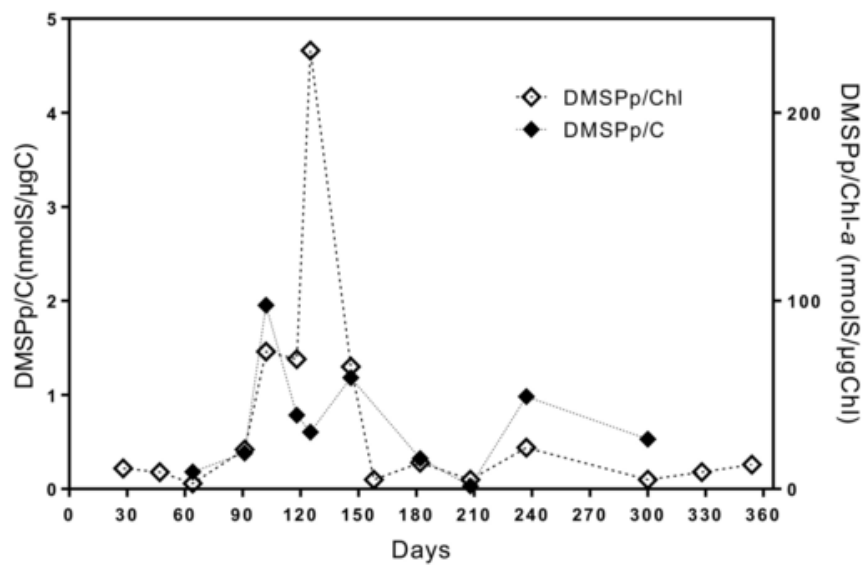

Fig. 10. Seasonal evolution of particulate dimethylsulfoniopropionate to Carbon (DM$\mathrm{SPp} / \mathrm{C})$ and DMSPp to Chlorophyll- $a(\mathrm{Chl}-a)(\mathrm{DMSPp} / \mathrm{Chl}-a)$ ratios measured at the station 330 in 2016

Table 2

DMSPp:Chl- $a$ data from batch cultures and literature review. DMSPp:Chl- $a$ ratio from Keller et al. (1989) were re-calculated from DMSP:C ratio assuming an average C:Chl- $a$ of 60 ( $\mathrm{g}: \mathrm{g})$ for all species.

\begin{tabular}{|c|c|c|c|}
\hline & Species group & $\begin{array}{l}\text { DMSPp:Chla } \\
\text { (mmol:g) }\end{array}$ & Data from \\
\hline \multicolumn{4}{|l|}{ Diatoms } \\
\hline \multirow[t]{9}{*}{ Community 1} & Diatoms $(n=22)$ & $4 \pm 6$ & Stefels et al. (2007) \\
\hline & $\begin{array}{l}\text { Skeletonema } \\
\text { costatum }\end{array}$ & $35.3 \pm 6$ & $\begin{array}{l}\text { Laboratory culture, this } \\
\text { study }\end{array}$ \\
\hline & $\begin{array}{l}\text { Nitzschia } \\
\text { closterium }\end{array}$ & 13.8 & $\begin{array}{l}\text { Laboratory culture, this } \\
\text { study }\end{array}$ \\
\hline & $\begin{array}{l}\text { Nitzschia } \\
\text { closterium }\end{array}$ & 24.8 & Keller et al. (1989) \\
\hline & Thalassiosira spp. & 2.6 & Keller et al. (1989) \\
\hline & $\begin{array}{l}\text { Thalassiosira } \\
\text { rotula }^{\mathrm{a}}\end{array}$ & 10.5 & $\begin{array}{l}\text { Laboratory culture, this } \\
\text { study }\end{array}$ \\
\hline & $\begin{array}{l}\text { Asterionella } \\
\text { glacialis }\end{array}$ & 5.7 & $\begin{array}{l}\text { Laboratory culture, this } \\
\text { study }\end{array}$ \\
\hline & $\begin{array}{l}\text { Asterionella } \\
\text { glacialis }\end{array}$ & N.D. & Keller et al. (1989) \\
\hline & $\begin{array}{l}\text { Ditylum } \\
\text { brightwellii }\end{array}$ & 6.0 & Keller et al. (1989) \\
\hline \multirow[t]{2}{*}{ Community 2} & $\begin{array}{l}\text { Chaetoceros } \\
\text { socialis }\end{array}$ & N.D. & $\begin{array}{l}\text { Laboratory culture, this } \\
\text { study }\end{array}$ \\
\hline & $\begin{array}{l}\text { Chaetoceros } \\
\text { debilis }^{\mathrm{a}}\end{array}$ & 0.8 & $\begin{array}{l}\text { Laboratory culture, this } \\
\text { study }\end{array}$ \\
\hline Community 3 & $\begin{array}{l}\text { Guinardia } \\
\text { delicatula }^{\mathrm{a}}\end{array}$ & 1.9 & $\begin{array}{l}\text { Laboratory culture, this } \\
\text { study }\end{array}$ \\
\hline \multicolumn{4}{|l|}{ Haptophytes } \\
\hline & $\begin{array}{l}\text { Haptophytes } \\
(\mathrm{n}=32)\end{array}$ & $52 \pm 37$ & Stefels et al. (2007) \\
\hline & $\begin{array}{l}\text { Phaeocystis } \\
\text { globosa }\end{array}$ & 95.25 & $\begin{array}{l}\text { Laboratory culture, this } \\
\text { study }\end{array}$ \\
\hline & $\begin{array}{l}\text { Phaeocystis } \\
\text { globosa }\end{array}$ & 67.0 & Keller et al. (1989) \\
\hline \multicolumn{4}{|l|}{ Dinoflagellates } \\
\hline & $\begin{array}{l}\text { Dinoflagellates } \\
(\mathrm{n}=32)\end{array}$ & $111 \pm 168$ & Stefels et al. (2007) \\
\hline
\end{tabular}

${ }^{a}$ Indicates cultures growing in K-medium instead of F/2 North Sea-medium.

\section{References}

Archer, S.D., Gilbert, F.J., Nightingale, P.D., Zubkov, M.V., Taylor, A.H., Smith, G.C., Burkill, P.H., 2002. Transformation of dimethylsulphoniopropionate to dimethyl sulphide during summer in the North Sea with an examination of key processes via a modelling approach. Deep-Sea Res. II 49, 3067-3101. van den Berg, A.J., Turner, S.M., van Duyl, F.C., Ruardij, P., 1996. Model structure and analysis of dimethylsulphide (DMS) production in the Southern North Sea, considering phytoplankton dimethylsulphoniopropionate-(DMSP) lyase and eutrophication effects. Mar. Ecol. Prog. Ser. 145, 233-244.

Borges, A.V., Champenois, W., 2017. Preservation protocol for dimethylsulfoniopropionate and dimethylsulfoxide analysis in plant material of the Mediterranean seagrass Posidonia oceanica, and re-evaluation of dimethylsulfoniopropionate leaf content. Aquat. Bot. 143C, 8-10.

Borges, A.V., Speeckaert, G., Champenois, W., Scranton, M.I., Gypens, N., 2017. Productivity and temperature as drivers of seasonal and spatial variations of dissolved methane in the Southern Bight of the North Sea. Ecosystems https://doi.org/10. 1007/s10021-017-0171-7.

Breton, E., Rousseau, V., Parent, J.Y., Ozer, J., Lancelot, C., 2006. Hydroclimatic modulation of diatom/Phaeocystis blooms in the nutrient-enriched Belgian coastal waters (North Sea). Limnol. Oceanogr. 51 (3), 1401-1409.

Charlson, R.J., Lovelock, J.E., Andreae, M.O., Warren, S.G., 1987. Oceanic phytoplankton, atmospheric sulfur, cloud albedo and climate. Nature 326, 655-661.

Cloern, J.E., Jassby, A.D., 1995. Year-to-year fluctuation of the spring phytoplankton bloom in South San Francisco Bay: an example of ecological variability at the land-sea interface. In: Ecological Time Series Springer, pp. 139-149 http://link springer.com/chapter/10.1007/978-1-4615-1769-6 10.

van Duyl, F.C., Gieskes, W.W.C., Kop, A.J., Lewis, W.E., 1998. Biological control of short-term variations in the concentration of DMSP and DMS during a Phaeocystis spring bloom. J. Sea Res. 40, 221-231.

Elliott, A.C., Woodward, W.A., 2007. Statistical Analysis Quick Reference Guidebook With SPSS Examples, 1st ed. Sage Publications, London.

Eppley, R.W., Harrison, W.G., Chisholm, S.W., Stewart, E., 1977. Particulate organic matter in surface waters off Southern California and its relationship to phytoplankton. J. Mar. Res. 35, 671-696.

Green, T.K., Hatton, A.D., 2014. The claw hypothesis: a new perspective on the role of biogenic sulphur in the regulation of global climate. Oceanogr. Mar. Biol. Annu. Rev. 52, 315-336.

Gypens, N., Borges, A.V., 2014. Increase in dimethylsulfide (DMS) emissions due to eutrophication of coastal waters offsets their reduction due to ocean acidification. Front. Mar. Sci. Mar. Ecosyst. Ecol. 1, 4. https://doi.org/10.3389/fmars.2014. 00004.

Gypens, N., Borges, A.V., Lancelot, C., 2009. Effect of eutrophication on air-sea $\mathrm{CO}_{2}$ fluxes in the coastal Southern North Sea: a model study of the past 50 years. Glob. Chang. Biol. 15 (4), 1040-1056.

Gypens, N., Borges, A.V., Speeckaert, G., Lancelot, C., 2014. The dimethylsulfide cycle in the eutrophied Southern North Sea: a model study integrating phytoplankton and bacterial processes. PLoS One 9 (1), e85862.

Harada, H., Kiene, R.P., 2011. Assessment and characteristics of DMSP lyase activity in seawater and phytoplankton cultures. In: http://repository.kulib.kyoto-u.ac.jp/ dspace/handle/2433/159487.

Hasle, G.R., 1978. The inverted microscope method. In: Phytoplankton Manual. UNESCO, Paris, pp. 88-96.

Hatton, A.D., 2002. DMSP removal and DMSO production in sedimenting particulate matter in the Northern North Sea. Deep-Sea Res. II Top. Stud. Oceanogr. 49 (15), 3053-3065.

Hatton, A.D., Wilson, S.T., 2007. Particulate dimethylsulphoxide and dimethylsulphoniopropionate in phytoplankton cultures and Scottish coastal waters. Aquat. Sci. 69 (3), 330-340.

Hatton, A.D., Malin, G., Turner, S.M., Liss, P.S., 1996. DMSO. In: Biological and Environmental Chemistry of DMSP and Related Sulfonium Compounds. Springer, pp. 405-412 http://link.springer.com/chapter/10.1007/978-1-4613-0377-0 35.

Hatton, A.D., Darroch, L., Malin, G., 2004. The role of dimethylsulphoxide in the marine biogeochemical cycle of dimethylsulphide. Oceanogr. Mar. Biol. Annu. Rev. $42,29-55$.

Hillebrand, H., Dürselen, C.-D., Kirschtel, D., Pollingher, U., Zohary, T., 1999. Biovolume calculation for pelagic and benthic microalgae. J. Phycol. 35 (2), 403-424.

Holm-Hansen, O., Lorenzen, C.J., Holmes, R.W., Strickland, J.D.H., 1965. Fluorometric determination of chlorophyll. J. Conseil. 30 (1), 3-15. https://doi.org/10.1093/ icesjms $/ 30.1 .3$

Keller, M.D., Selvin, R.C., Claus, W., Guillard, R.R.L., 1987. Media for the culture of oceanic ultraphytoplankton. J. Phycol. 23, 633-638.

Keller, M.D., Bellows, W.K., Guillard, R.R.L., 1989. Dimethyl sulfide production in marine phytoplankton. In: Saltzman, E.S., Cooper, W.J. (Eds.), Biogenic Sulfur in the Environment. American Chemical Society, Washington DC, pp. 167-182.

Kettle, A.J., Andreae, M.O., Amouroux, D., Andreae, T.W., Bates, T.S., Berresheim, H., Bingemer, H., et al., 1999. A global database of sea surface dimethylsulfide (DMS) measurements and a procedure to predict sea surface DMS as a function of latitude, longitude, and month. Glob. Biogeochem. Cycles 13 (2), 399-444.

Kiene, R.P., Gerard, G., 1994. Determination of trace levels of dimethylsulfoxide (DMSO) in seawater and rainwater. Mar. Chem. 47 (1), 1-12.

Kiene, R.P., Linn, L.J., 2000. On the fate of DMSP-sulfur in seawater: tracer studies with dissolved 35S-DMSP. Geochim. Cosmochim. Acta 64, 2797-2810 
Kiene, R.P., Linn, L.J., 2000. Distribution and turnover of dissolved DMSP and its relationship with bacterial production and dimethylsulfide in the Gulf of Mexico. Limnol. Oceanogr. 45, 848-861.

Kiene, R.P., Slezak, D., et al., 2006. Low dissolved DMSP concentrations in seawater revealed by small-volume gravity filtration and dialysis sampling. Limnol. Oceanogr. Methods 4, 80-95.

Kiene, R.P., Linn, L.J., Bruton, J.A., 2000. New and important roles for DMSP in marine microbial communities. J. Sea Res. 43 (3), 209-224.

Kirst, G.O., Thiel, C., Wolff, H., Nothnagel, J., Wanzek, M., Ulmke, R., 1991. Dimethylsulfoniopropionate (DMSP) in ice-algae and its possible biological role. Mar. Chem. 35, 381-388.

Kwint, R.L.J., Kramer, K.J.M., 1996. Annual cycle of the production and fate of DMS and DMSP in a marine coastal system. Mar. Ecol. Prog. Ser. 134, 217-224.

Lana, A., Bell, T.G., Simó, R., Vallina, S.M., Ballabrera-Poy, J., Kettle, A.J., et al., 2011. An updated climatology of surface dimethlysulfide concentrations and emission fluxes in the global ocean. Glob. Biogeochem. Cycles 25, GB1004https://doi. org/10.1029/2010GB003850.

Lancelot, C., Spitz, Y., Gypens, N., Ruddick, K., Becquevort, S., et al., 2005. Modelling diatom and Phaeocystis blooms and nutrient cycles in the Southern Bight of the North Sea: the MIRO model. Mar. Ecol. Prog. Ser. 289, 63-78.

Lancelot, C., Gypens, N., Billen, G., Garnier, J., Roubeix, V., 2007. Testing an integrated river-ocean mathematical tool for linking marine eutrophication to land use: the Phaeocystis-dominated Belgian coastal zone (Southern North Sea) over the past 50 years. J. Mar. Syst. 64 (14), 216-228

Liss, P.S., Malin, G., Turner, S.M., Holligan, P.M., 1994. Dimethyl sulfide and Phaeocystis - a review. J. Mar. Syst. 5, 41-53.

Masotti, I., Belviso, S., Alvain, S., Johnson, J.E., Bates, T.S., Tortell, P.D., Kasamatsu, N., Mongin, M., Marandino, C.A., Saltzman, E.S., Moulin, C., 2010. Spatial and temporal variability of the dimethylsulfide to chlorophyll ratio in the surface ocean: an assessment in the light of phytoplankton composition determined from space. Biogeosci. Discuss. 7 (3), 3605-3650.

Menden-Deuer, S., Lessard, E.J., 2000. Carbon to volume relationships for dinoflagellates, diatoms, and other protist plankton. Limnol. Oceanogr. 45 (3), 569-579.

Miles, J., 2014. Tolerance and variance inflation factor. In: Wiley Stats Ref: Statistics Reference Online. John Wiley \& Sons, Ltd. https://oi.org/10.1002 9781118445112.stat06593.

Pallant, J., 2007. SPSS Survival Manual, a Step by Step Guide to Data Analysis Using SPSS for Windows, 3 ed. McGraw Hill, Sydney, 179-200.

Quinn, P.K., Bates, T.S., 2011. The case against climate regulation via oceanic phytoplankton sulphur emissions. Nature 480 (7375), 51-56. https://doi.org/10.1038/ nature 10580 .

Rousseau, V., Mathot, S., Lancelot, C., 1990. Calculating carbon biomass of Phaeocystis sp. from microscopic observations. Mar. Biol. 107, 305-314.

Rousseau, V., Becquevort, S., Parent, J.Y., Gasparini, S., Daro, M.H., Tackx, M., Lancelot, C., 2000. Trophic efficiency of the planktonic food web in a coastal ecosystem dominated by Phaeocystis colonies. J. Sea Res. 43, 357-372.

Rousseau, V., Leynaert, A., Daoud, N., Lancelot, C., 2002. Diatom succession, silicification and silicic acid availability in Belgian coastal waters (Southern Bight of the North Sea). Mar. Ecol. Prog. Ser. 236, 61-73.

Rousseau, V., Park, Y., Ruddick, K., Vyverman, W., Parent, J.P., Lancelot, C., Cox, D., 2006. Phytoplankton blooms in response to nutrient enrichment. In: Current Status of Eutrophication in the Belgian Coastal Zone. pp. 45-59.
Simó, R., Vila-Costa, M., 2006. Ubiquity of algal dimethylsulfoxide in the surface ocean: geographic and temporal distribution patterns. Mar. Chem. 100 (1-2), 136-146. https://doi.org/10.1016/j.marchem.2005.11.006.

Simó, R., Hatton, A.D., Malin, G., Liss, P.S., 1998. Particulate dimethyl sulphoxide in seawater: production by microplankton. Mar. Ecol. Prog. Ser. 167, 291-296.

Steele, J.H., Baird, I.E., 1962. Further relations between primary production, chlorophyll, and particulate carbon. Limnol. Oceanogr. 7 (1), 42-44.

Stefels, J., 2000. Physiological aspects of the production and conversion of DMSP in marine algae and higher plants. J. Sea Res. 43, 183-197.

Stefels, J., 2009. Determination of DMS, DMSP, and DMSO in seawater. In: Practical Guidelines for the Analysis of Seawater. p. 223.

Stefels, J., Dijkhuizen, L., Gieskes, W.W.C., 1995. DMSP-lyase activity in a spring phytoplankton bloom off the Dutch coast, related to Phaeocystis sp. abundance. Mar. Ecol. Prog. Ser. 123, 235-243.

Stefels, J., Gieskes, W.C., Dijkhuizen, L., 1996. Intriguing functionality of the production and conversion of DMSP in Phaeocystis sp.. In: Biological and Environmental Chemistry of DMSP and Related Sulfonium Compounds. Springer, pp. 305-315. https://doi.org/10.1007/978-1-4613-0377-0 26.

Stefels, J., Steinke, M., Turner, S., Malin, G., Belviso, S., 2007. Environmental constraints on the production and removal of the climatically active gas dimethylsulphide (DMS) and implications for ecosystem modelling. Biogeochemistry 83 (1-3), 245-275. https://doi.org/10.1007/s10533-007-9091-5.

Steinke, M., Malin, G., Liss, P.S., 2002. Trophic interactions in the sea: an ecological role for climate relevant volatiles?. J. Phycol. ISSN: 0022-3646, 38 (4), 630-638.

Sunda, W.K.D.J., Kieber, D.J., Kiene, R.P., Huntsman, S., 2002. An antioxidant function for DMSP and DMS in marine algae. Nature 418 (6895), 317-320.

Turner, S.M., Malin, G., Liss, P.S., Harbour, D.S., Holligan, P.M., 1988. The seasonal variation of dimethyl sulphide and DMSP concentrations in nearshore waters. Limnol. Oceanogr. 33, 364-375.

Turner, S.M., Malin, G., Nightingale, P.D., Liss, P.S., 1996. Seasonal variation of dimethyl sulphide in the North Sea and an assessment of fluxes to the atmosphere. Mar. Chem. 54, 245-262.

Vairavamurthy, A., Andreae, M.O., Iverson, R.L., 1985. Biosynthesis of dimethylsulfide and dimethylpropiothetin by Hymenomonas carterae in relation to sulfur source and salinity variations. Limnol. Oceanogr. 30, 59-70.

Verity, P.G., Smayda, T.J., Sakshaug, E., 1991. Photosynthesis, excretion, and growth rates of Phaeocystis colonies and solitary cells. Polar Res. 10 (1), 117-128.

VLIZ, 2017. Flanders Marine Institute (VLIZ), Belgium (2017): LifeWatch Observatory Data: Nutrient, Pigment, Suspended Matter and Secchi Measurements in the Belgian Part of the North Sea. https://doi.org/10.14284/301.

Wang, S., Elliott, S., Maltrud, M., Cameron-Smith, P., 2015. Influence of explicit Phaeocystis parameterizations on the global distribution of marine dimethyl sulfide. J. Geophys. Res. 2158-2177.

Welschmeyer, N.A., Lorenzen, C.J., 1984. Carbon-14 labeling of phytoplankton carbon and chlorophyll a carbon: determination of specific growth rates. Limnol. Oceanogr. 29 (1), 135-145.

Wolfe, G.V., Steinke, M., Kirst, G.O., 1997. Grazing-activated chemical defence in a unicellular marine alga. Nature 387, 894-897.

Wolfe, G.V., Strom, S.L., Holmes, J.L., et al., 2002. Dimethylsulfoniopropionate cleavage by marine phytoplankton in response to mechanical, chemical, or dark stress. J. Phycol. 38, 948-960. 